\title{
ANALISIS TOTAL PADATAN TAK LARUT AIR DAN SIFAT ORGANOLEPTIK MADU SAWO (Achras zapota L.)
}

\author{
Nela Eska Putri \\ Program Studi Ilmu dan Teknologi Pangan, Fakultas Pertanian, Universitas \\ Garut \\ E-mail : nelaeskaputri@uniga.ac.id
}

\begin{abstract}
ABSTRAK
Proses pengolahan seperti pemekatan atau pemasakan pada suhu tinggi berpengaruh terhadap kualitas madu sawo, baik secara fisik maupun secara kimia, sehingga pengolahan madu buah dilakukan dengan metode evaporasi (pemasakan dengan suhu dan tekanan yang lebih rendah). Penelitian tentang analisis total padatan tak larut air madu sawo didasarkan pada persyaratan normal madu sesuai dengan SNI No. 01-3545-2004. Selanjutnya dianalisis sifat organoleptiknya meliputi warna, aroma, dan kekentalan pada rentang nilai 1-5 (tidak suka, kurang suka, agak suka, suka, dan sangat suka). Setelah itu dilakukan uji pembeda madu sawo dengan madu asli dan sampel madu kurma. Madu sawo dibuat dengan metode evaporasi menggunakan evaporator vakum dengan kombinasi perlakuan suhu $\left(40^{\circ} \mathrm{C}\left(\mathrm{A}_{1}\right), 50^{\circ} \mathrm{C}\left(\mathrm{A}_{2}\right)\right.$, dan $\left.60^{\circ} \mathrm{C}\left(\mathrm{A}_{3}\right)\right)$ dan waktu $\left(8 \mathrm{jam}\left(\mathrm{B}_{1}\right), 10 \mathrm{jam}\left(\mathrm{B}_{2}\right)\right.$, dan 12 jam $\left.\left(\mathrm{B}_{3}\right)\right)$. Hasil penelitian menunjukkan bahwa kenaikan suhu dan waktu dapat meningkatkan persentase total padatan tak larut air pada madu sawo. Madu sawo yang dievaporasi pada suhu $60^{\circ} \mathrm{C}$ selama $10 \mathrm{jam}\left(\mathrm{A}_{3} \mathrm{~B}_{2}\right)$ memiliki rata-rata nilai warna 3,75 (agak suka sampai suka), rata-rata nilai aroma 3,05 agak suka sampai suka), dan rata-rata nilai kekentalan sebesar 4,35 (suka sampai sangat suka). Hasil uji beda madu menunjukkan bahwa madu sawo tidak lebih disukai dibandingkan madu asli, tetapi lebih disukai dibandingkan madu kurma.
\end{abstract}

Kata kunci: Evaporasi, madu sawo, sifat organoleptik madu sawo, SNI madu, total padatan tak larut air

\section{PENDAHULUAN}

Sawo merupakan tanaman tahunan yang berbuah sepanjang musim. Sawo banyak ditanam sebagai tanaman pekarangan sampai tanaman perkebunan. Tanaman sawo optimal dibudidayakan pada daerah yang beriklim basah sampai kering. Menurut data Badan Pusat Statistik Kabupaten Tanah Datar (Sumatera Barat) (2016), buah sawo dihasilkan sebanyak 2.345,40 ton di kabupaten tersebut 
pada tahun 2015. Sawo tersebut banyak ditanam di Kecamatan Batipuh Selatan, dengan jumlah produksi rata-rata di tahun 2015 adalah 19,93 ton/ha.

Tanaman sawo mengalami panen besar dan panen kecil. Tanaman sawo yang bibitnya berasal dari biji berbuah pada umur empat sampai lima tahun, sedangkan yang berasal dari cangkok dapat dipanen pada umur satu sampai dua tahun, atau bahkan kurang dari satu tahun. Menurut Kusmiyati et al. (2014), sawo mampu berbuah sebanyak 1000-3000 buah/pohon/musim panen atau setara dengan 50-150 kg. Sawo manila yang berusia 5-9 tahun mempunyai produktivitas antara 600-1000 buah/pohon/musim panen atau 30-50 kg. Menurut Balerdi et al. (2008), sawo memiliki rasa dari rentang manis hingga sangat manis, dengan kadar gula daging buah adalah sekitar 19-24 ${ }^{\circ}$ Brix. Menurut Astawan (2010), kandungan gula buah sawo adalah sekitar 16-20\%. Sedangkan pada saat mentah/muda sawo memiliki rasa yang sepat.

Menurut Jangam et al. (2008), sawo merupakan buah-buahan tropis yang mudah rusak karena kandungan airnya yang tinggi, sehingga untuk memperpanjang umur simpannya perlu dilakukan dehidrasi (penguapan air) dari pasta buah, seperti dengan pengeringan udara, pengeringan suhu rendah, dan pengeringan beku. Sari buah sawo dapat dipekatkan melalui pemanasan. Dalam pengolahan, pemekatan atau pemasakan pada suhu tinggi berpengaruh terhadap kualitas madu sawo itu sendiri, yaitu dapat mengurangi kecerahan warna dan menghilangkan nutrisi penting pada sari buah. Oleh karena itu perlu dilakukan pemanasan dalam keadan vakum, yaitu dengan suhu dan tekanan rendah.

Evaporasi merupakan proses pemisahan uap air dari larutan yang mengandung air relatif banyak, dimana molekul yang berada dalam fasa cair berubah menjadi fasa gas secara spontan. Tujuan proses evaporasi adalah untuk meningkatkan konsentrasi suatu zat dalam larutan tertentu. Penelitian Putri et al. (2018) sebelumnya tentang pengurangan kadar air sari buah sawo sudah dilakukan dengan menerapkan metode evaporasi pada suhu $60^{\circ} \mathrm{C}$ selama $10 \mathrm{jam}$, dengan mendapatkan kadar air sebesar 19,86\%. Sari buah yang dipekatkan ini disebut dengan madu buah sawo. Penetapan hasil terbaik pada beberapa perlakuan sehingga menghasilkan produk madu buah sawo adalah berdasarkan SNI madu nomor 01-3545-2004 yang ditetapkan oleh Bandar Standarisasi Nasional tahun 2004. Penelitian ini bertujuan untuk mengetahui total padatan terlarut pada madu buah sawo yang dibuat dengan berbagai perakuan sehingga memenuhi syarat SNI madu nomor 01-3545-2004, selain itu dilakukan uji kesukaan serta uji pembeda madu terhadap produk madu sawo terbaik.

\section{METODOLOGI}

Penelitian ini dilaksanakan di Laboratorium Kimia-Biokimia Hasil Pertanian dan Gizi Pangan, Teknologi Hasil Pertanian Universitas Andalas. Bahan 
yang digunakan dalam pembuatan madu buah adalah buah sawo manila matang yang berasal dari daerah Sumpur, Kecamatan Batipuh Selatan, Kabupaten Tanah Datar, Propinsi Sumatera Barat. Ciri-ciri buah matang adalah berwarna coklat kekuningan sampai kemerahan dan keadaan permukaan kulitnya bersisik kasar coklat yang mudah mengelupas. Untuk uji pembeda madu digunakan madu asli (merk dagang Madu Sumbawa) dan madu kurma (sampel madu buah yang beredar di pasaran dengan merk dagang Sari Kurma Jadied Propolis).

\section{Metode Pelaksanaan Penelitian (Putri et al., 2018)}

Buah sawo dipilih yang sudah masak lalu dibuang kulitnya. Buah dipotong kecil-kecil dan dibuang biji serta bagian buah yang busuk. Potongan buah ditimbang dan diukur berat bagian buah yang dapat dimakan (BDD). Buah sawo yang telah dipotong-potong lalu diblender atau digiling dengan sangat halus dan diperas untuk mendapatkan sari buahnya. Sari buah disaring dengan kain saring. Selanjutnya dilakukan pemekatan sari buah dengan menggunakan evaporator vakum (sesuai dengan perlakuan). Rancangan yang digunakan dalam penelitian ini adalah Rancangan Acak Lengkap (RAL) Faktorial dengan 2 faktor dan 3 ulangan. Faktor pertama dan kedua masing-masing terdiri dari 3 taraf. Data dianalisa secara statistik dengan uji F, kemudian dilanjutkan dengan uji Duncan New Multiple Range Test (DNMRT) pada taraf nyata 5\%.

Faktor pertama (A) adalah suhu evaporasi $\left({ }^{0} \mathrm{C}\right)$, yaitu:

$\mathrm{A}_{1}=\operatorname{suhu} 40^{\circ} \mathrm{C}$

$\mathrm{A}_{2}=$ suhu $50^{\circ} \mathrm{C}$

$\mathrm{A}_{3}=$ suhu $60^{\circ} \mathrm{C}$

Sedangkan faktor kedua (B) adalah lama evaporasi, yaitu:

$\mathrm{B}_{1}=8 \mathrm{jam}$

$\mathrm{B}_{2}=10 \mathrm{jam}$

$\mathrm{B}_{3}=12 \mathrm{jam}$

Kombinasi perlakuan antara kedua faktor tersebut adalah:

$\mathrm{A}_{1} \mathrm{~B}_{1}=$ evaporasi pada suhu $40^{\circ} \mathrm{C}$ selama 8 jam

$\mathrm{A}_{1} \mathrm{~B}_{2}=$ evaporasi pada suhu $40^{\circ} \mathrm{C}$ selama $10 \mathrm{jam}$

$\mathrm{A}_{1} \mathrm{~B}_{3}=$ evaporasi pada suhu $40^{\circ} \mathrm{C}$ selama $12 \mathrm{jam}$

$\mathrm{A}_{2} \mathrm{~B}_{1}=$ evaporasi pada suhu $50^{\circ} \mathrm{C}$ selama $8 \mathrm{jam}$

$\mathrm{A}_{2} \mathrm{~B}_{2}=$ evaporasi pada suhu $50^{\circ} \mathrm{C}$ selama $10 \mathrm{jam}$

$\mathrm{A}_{2} \mathrm{~B}_{3}=$ evaporasi pada suhu $50^{\circ} \mathrm{C}$ selama $12 \mathrm{jam}$

$\mathrm{A}_{3} \mathrm{~B}_{1}=$ evaporasi pada suhu $60^{\circ} \mathrm{C}$ selama 8 jam

$\mathrm{A}_{3} \mathrm{~B}_{2}=$ evaporasi pada suhu $60^{\circ} \mathrm{C}$ selama 10 jam

$\mathrm{A}_{3} \mathrm{~B}_{3}=$ evaporasi pada suhu $60^{\circ} \mathrm{C}$ selama $12 \mathrm{jam}$ 


\section{Pengamatan}

Pengamatan terhadap total padatan yang tak larut dalam air madu buah sawo sesuai dengan SNI gula SNI 01-2891-1992. Ditimbang 5 g sampel dan dilarutkan di dalam air panas sebanyak $100 \mathrm{ml}$. Kemudian disaring dengan kertas saring yang telah diketahui bobot tetapnya. Lalu dicuci dengan air panas. Selanjutnya kertas saring yang telah berisi zat-zat tak larut dalam air dikeringkan pada suhu $100-105{ }^{\circ} \mathrm{C}$ dalam oven selama 2 jam, kemudian didinginkan dalam desikator dan ditimbang sampai bobotnya tetap.

padatan tak larut air $=\frac{\text { zat yang tak larut }(\mathrm{g})}{\text { berat sampel }(\mathrm{g})} \times 100 \%$

Uji organoleptik terhadap warna, aroma, dan kekentalan, serta uji pembeda madu. Uji organoleptik dilakukan dengan uji hedonic atau uji kesukaan terhadap beberapa formulasi pasta buah yang dihasilkan. Dari hasil pengujian organoleptik dianalisis secara deskriptif menggunakan skor modus dan persentase panelis yang dapat menerima.

Skor penilaian yang diberikan pada uji organoleptik adalah:

$$
\begin{aligned}
& 1=\text { tidak suka } \\
& 2=\text { kurang suka, } \\
& 3=\text { agak suka } \\
& 4=\text { suka } \\
& 5=\text { sangat suka. }
\end{aligned}
$$

Persentase penerimaan panelis dihitung dengan cara menghitung persentase rasio jumlah panelis yang dapat menerima produk, yaitu agak suka (3), suka (4), dan sangat suka (5) dengan jumlah total panelis. Uji pembeda madu dilakukan terhadap madu buah sawo (perlakuan terbaik) dibandingkan dengan madu asli (merk dagang Madu Sumbawa), madu kurma (sampel madu buah yang beredar di pasaran dengan merk dagang Sari Kurma Jadied Propolis) dan madu sawo yang dimasak dengan api kompor.

Skor yang diberikan adalah:

$1=$ lebih suka daripada, dan

$2=$ tidak suka daripada.

\section{HASIL DAN PEMBAHASAN}

\section{Total Padatan Tak Larut Air}

Berdasarkan hasil analisis sidik ragam yang dilihat pada Tabel 1., suhu dan lama evaporasi berpengaruh nyata terhadap total padatan tak larut air madu buah sawo yang dihasilkan. Interaksi antara kedua faktor tersebut juga 
menunjukkan berbeda nyata terhadap total padatan tak larut air madu buah sawo yang dihasilkan. Hal tersebut dapat juga dilihat pada Gambar 1.

Tabel 1. Pengaruh Suhu (Faktor A) Dan Lama Evaporasi (faktor B) Terhadap Total Padatan Tak Larut Air (\%) Madu Buah Sawo.

\begin{tabular}{llllll}
\hline \multirow{2}{*}{ Suhu $(\mathbf{A})$} & \multicolumn{3}{c}{ Lama evaporasi $(\mathbf{B})$} & \multicolumn{2}{c}{ Rata-rata faktor } \\
\cline { 2 - 4 } & $\mathbf{8}$ jam $\left(\mathbf{B}_{1}\right)$ & $\mathbf{1 0}$ jam $\left(\mathbf{B}_{2}\right)$ & $\mathbf{1 2} \mathbf{j a m}\left(\mathbf{B}_{3}\right)$ & \multicolumn{2}{c}{$\mathbf{A}$} \\
\hline $40^{\circ} \mathrm{C}\left(\mathrm{A}_{1}\right)$ & $1.04 \mathrm{e}$ & $1.11 \mathrm{de}$ & $1.22 \mathrm{~d}$ & $1.13 \mathrm{C}$ \\
$50^{\circ} \mathrm{C}\left(\mathrm{A}_{2}\right)$ & $1.64 \mathrm{c}$ & $1.18 \mathrm{de}$ & $1.58 \mathrm{c}$ & $1.47 \mathrm{~B}$ \\
$60^{\circ} \mathrm{C}\left(\mathrm{A}_{3}\right)$ & $1.85 \mathrm{~b}$ & $1.17 \mathrm{de}$ & $2.03 \mathrm{a}$ & $1.68 \mathrm{~A}$ \\
\hline Rata-rata faktor & $1.51 \mathrm{~B}$ & $1.15 \mathrm{C}$ & $1.61 \mathrm{~A}$ & \\
B & & & & & \\
\hline KK & $4.10 \%$ & & & & \\
\hline
\end{tabular}

Keterangan : Angka-angka pada kolom dan baris yang diikuti oleh huruf kecil yang sama, angka-angka pada kolom rata-rata faktor A dan angkaangka pada baris rata-rata faktor B yang diikuti oleh huruf besar yang sama, berbeda tidak nyata menurut uji Duncan pada taraf nyata $5 \%$.

Berdasarkan hasil penelitian Putri et al. (2018), madu buah sawo yang dihasilkan pada suhu evaporasi $60^{\circ} \mathrm{C}$ selama 10 jam memiliki karakteristik seperti madu, dengan kadar air 19,86\%, kadar gula pereduksi (dihitung sebagai glukosa) $74,75 \%$, kadar sukrosa 4,42\%, dan kadar keasaman 40,16 ml NaOH 1 N/kg. Pada Tabel 1. terlihat bahwa madu buah sawo yang dipekatkan pada suhu $60^{\circ} \mathrm{C}$ selama 10 jam memiliki kandungan padatan tak larut air sebesar $1,17 \%$, sedangkan menurut SNI madu No. 01-3545-2004 total padatan tak larut air dalam madu asli adalah maksimal $0,5 \%$ (b/b). Hal ini sejalan dengan tingginya kadar abu madu sawo, yaitu 2,20\% (Putri et al. 2018) yang juga lebih tinggi dari syarat maksimal kadar abu madu $(0,5 \%$ b/b) menurut SNI No. 01-3545-2004. Hal ini bisa menandakan bahwa kandungan mineral dalam madu sawo lebih tinggi dibandingkan kandungan mineral madu asli. Seperti pendapat Astawan (2010) bahwa sawo memiliki kandungan mineral yang cukup baik, seperti kalsium, kalium, magnesium, pospor, selenium, seng, dan tembaga. Tingginya kadar abu secara umum juga sebanding dengan total padatan tak larut air madu sawo. 


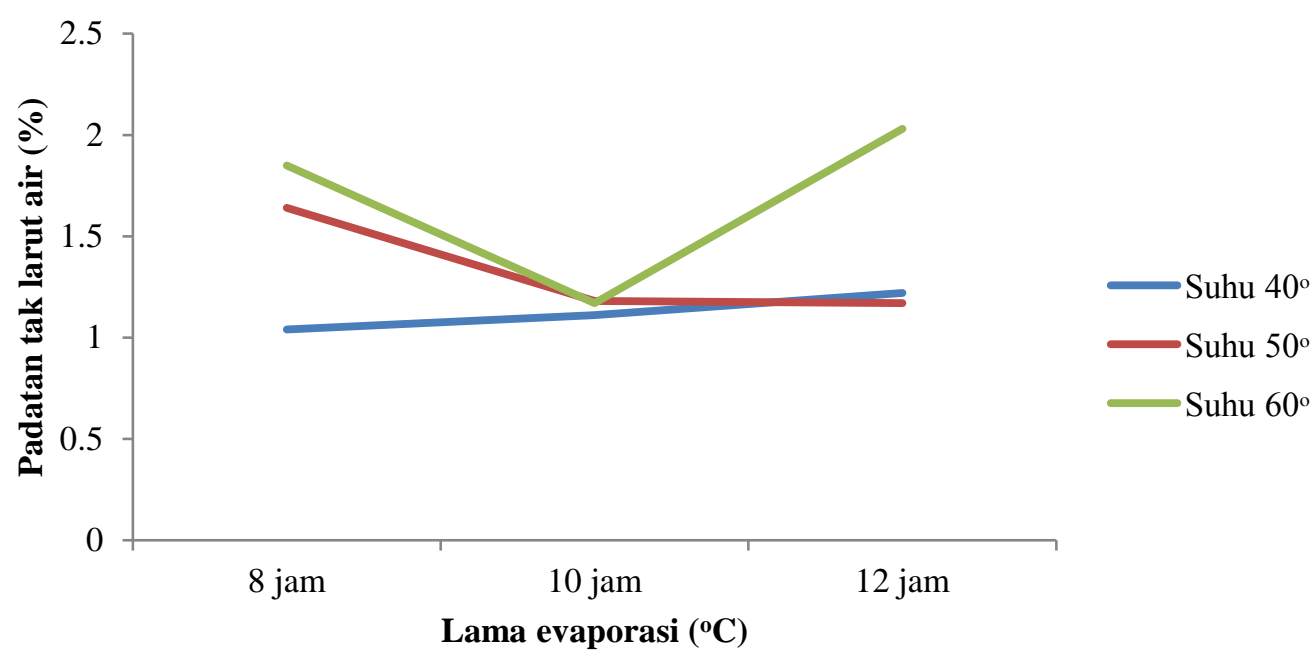

Gambar 1. Pengaruh Suhu Dan Lama Evaporasi Terhadap Total Padatan Tak Larut Air Madu Buah Sawo.

\section{Sifat Organoleptik}

Mutu madu sawo yang dihasilkan telah diuji sifat organoleptiknya terhadap warna, aroma dan kekentalan. Produk madu sawo yang mendapatkan respon terbaik (menyerupai madu) dan memiliki kandungan kimia mendekati madu dilakukan uji pembeda terhadap madu asli dan madu buah kurma (sampel madu buah yang beredar di pasar).

\section{Warna}

Secara visual faktor warna tampil lebih dahulu dan kadang-kadang sangat menentukan. Warna madu buah sawo dapat berasal dari pigmen alami yang terdapat pada buah sawo itu sendiri ataupun berasal dari proses pemekatan (evaporasi). Berdasarkan hasil perhitungan penilaian panelis terhadap warna madu buah sawo yang dihasilkan, dihitung rata-rata tingkat kesukaannya dan dapat dilihat pada Tabel 2 .

Tabel 2. Tingkat kesukaan panelis terhadap warna madu buah sawo.

\begin{tabular}{|c|c|c|c|c|}
\hline \multirow{2}{*}{ Suhu (A) } & \multicolumn{3}{|c|}{ Lama evaporasi (B) } & \multirow{2}{*}{$\begin{array}{l}\text { Rata-rata } \\
\text { faktor } A\end{array}$} \\
\hline & 8 jam $\left(B_{1}\right)$ & 10 jam $\left(B_{2}\right)$ & 12 jam $\left(B_{3}\right)$ & \\
\hline $40^{\circ} \mathrm{C}\left(\mathrm{A}_{1}\right)$ & 2.65 & 3.55 & 2.90 & 3.03 \\
\hline $50^{\circ} \mathrm{C}\left(\mathrm{A}_{2}\right)$ & 2.15 & 3.05 & 2.55 & 2.58 \\
\hline $60^{\circ} \mathrm{C}\left(\mathrm{A}_{3}\right)$ & 3.50 & 3.75 & 4.40 & 3.88 \\
\hline $\begin{array}{l}\text { Rata-rata } \\
\text { faktor B }\end{array}$ & 2.77 & 3.45 & 3.28 & \\
\hline
\end{tabular}

Keterangan :

$1=$ tidak suka, $2=$ kurang suka, $3=$ agak suka, $4=$ suka, $5=$ sangat suka 
Dari Tabel 2. terlihat bahwa nilai rata-rata tertinggi untuk warna produk adalah 4,40 yang berada pada taraf suka. Kesukaan konsumen terhadap warna disebabkan karena madu sawo berwarna coklat sampai coklat tua akibat adanya perlakuan suhu dan lama penguapan. Warna madu buah sawo yang coklat dan semakin pekat disebabkan karena kadar airnya menurun, sehingga kekentalan dan kerapatan bahan semakin tinggi. Sedangkan nilai terendah kesukaan konsumen terhadap warna adalah 2,15 yang berada pada taraf kurang suka. Produk pada range ini berwarna coklat muda agak kekuningan dan masih menyerupai sari buah sawo itu sendiri. Produk $\mathrm{A}_{3} \mathrm{~B}_{2}$ sendiri yang memiliki kandungan kimia menyerupai madu (Putri et al., 2018) memiliki nilai rata-rata warna 3,75 (agak suka sampai suka).

\section{Aroma}

Selain warna, bau atau aroma juga menentukan kualitas suatu bahan pangan. Aroma suatu bahan dapat tercium karena menguapnya senyawa-senyawa tertentu pada bahan tersebut. Madu buah sawo menghasilkan aroma khas buah sawo dan sedikit beraroma gula. Berdasarkan hasil perhitungan penilaian panelis terhadap aroma madu sawo yang dihasilkan, dihitung rata-rata tingkat kesukaannya dan dapat dilihat pada Tabel 3.

Tabel 3. Tingkat kesukaan panelis terhadap aroma madu buah sawo

\begin{tabular}{lllll}
\hline \multirow{2}{*}{ Suhu (A) } & \multicolumn{3}{c}{ Lama evaporasi $(\mathrm{B})$} & \multirow{2}{*}{ Rata-rata faktor A } \\
\cline { 2 - 5 } & 8 jam $\left(\mathrm{B}_{1}\right)$ & 10 jam $\left(\mathrm{B}_{2}\right)$ & 12 jam $\left(\mathrm{B}_{3}\right)$ & \\
\hline $40^{0} \mathrm{C}\left(\mathrm{A}_{1}\right)$ & 4.50 & 4.40 & 4.20 & 4.37 \\
$50^{\circ} \mathrm{C}\left(\mathrm{A}_{2}\right)$ & 3.50 & 3.30 & 3.75 & 3.52 \\
$60^{\circ} \mathrm{C}\left(\mathrm{A}_{3}\right)$ & 3.00 & 3.05 & 3.00 & 3.02 \\
\hline Rata-rata faktor B & 3.67 & 3.65 & 3.58 \\
\hline
\end{tabular}

Keterangan :

$1=$ tidak suka, $2=$ kurang suka, $3=$ agak suka, $4=$ suka, $5=$ sangat suka

Dari Tabel 3. dapat dilihat bahwa kenaikan suhu dapat menurunkan kualitas aroma madu buah sawo. Evaporasi pada suhu terendah $\left(40^{\circ} \mathrm{C}\right)$ rata-rata memberikan penilaian yang tinggi terhadap aroma, yaitu sekitar 4,37 yang berada pada taraf suka. Aroma yang dirasakan pada produk-produk ini masih memiliki aroma sari buah sawo yang kuat dan masih segar, sehingga disukai oleh konsumen. Sedangkan tingkat kesukaan terendah berada pada produk yang dievaporasi pada suhu $60^{\circ} \mathrm{C}$ dengan rata-rata 3,02, yaitu berada pada range agak suka. Aroma yang tercium pada produk-produk ini adalah aroma gula dengan sedikit aroma buah sawo.

Menurut Winarno (2004), hasil reaksi yang menimbulkan warna coklat kadang-kadang menjadi pertanda penurunan mutu. Warna coklat timbul karena produk semakin pekat, gulanya juga semakin kental, sehingga aroma gula tercium 
agak kuat. Produk $\mathrm{A}_{3} \mathrm{~B}_{2}$ yang memenuhi syarat kadar air madu dan memiliki kandungan kimia lainnya yang menyerupai madu (Putri et al., 2018) memiliki aroma yang disukai oleh panelis, yaitu sebesar 3,05 (agak suka sampai suka).

\section{Kekentalan}

Kekentalan madu buah sawo yang dihasilkan berhubungan dengan kadar air dan total padatan tak larut air. Kekentalan yang diharapkan adalah kekentalan madu buah sawo yang menyerupai kekentalan madu asli. Berdasarkan hasil perhitungan penilaian panelis terhadap kekentalan madu sawo yang dihasilkan, dihitung rata-rata tingkat kesukaannya dan dapat dilihat pada Tabel 4.

Tabel 4. Tingkat kesukaan panelis terhadap kekentalan madu buah sawo.

\begin{tabular}{lllll}
\hline \multirow{2}{*}{ Suhu $(\mathbf{A})$} & \multicolumn{3}{c}{ Lama evaporasi $(\mathbf{B})$} & $\begin{array}{c}\text { Rata-rata } \\
\text { faktor } \mathbf{A}\end{array}$ \\
\cline { 2 - 4 } & $\mathbf{8}$ jam $\left(\mathbf{B}_{\mathbf{1}}\right)$ & $\mathbf{1 0}$ jam $\left(\mathbf{B}_{2}\right)$ & $\mathbf{1 2}$ jam $\left(\mathbf{B}_{3}\right)$ & 1.50 \\
\hline $40^{\circ} \mathrm{C}\left(\mathrm{A}_{1}\right)$ & 1.50 & 1.50 & 1.50 & 1.63 \\
$50^{\circ} \mathrm{C}\left(\mathrm{A}_{2}\right)$ & 1.65 & 1.60 & 1.65 & 3.68 \\
$60^{\circ} \mathrm{C}\left(\mathrm{A}_{3}\right)$ & 4.25 & 4.35 & 2.45 & \\
\hline $\begin{array}{c}\text { Rata-rata faktor } \\
\quad \text { B }\end{array}$ & 2.47 & 2.48 & 1.87 & \\
\hline
\end{tabular}

Keterangan :

1 = tidak suka, 2 = kurang suka, $3=$ agak suka, $4=$ suka, $5=$ sangat suka

Berdasarkan Tabel 4., menurut panelis produk yang dievaporasi pada suhu $40^{\circ} \mathrm{C}$ dan $50^{\circ} \mathrm{C}$ masing-masing memiliki kekentalan rata-rata 1,50 dan 1,63 yang berada pada taraf tidak suka sampai kurang suka. Produk-produk tersebut masih encer seperti sari buah dan belum mengental seperti madu. Produk mulai mengental pada evaporasi dengan suhu $60^{\circ} \mathrm{C}$, sehingga rata-rata tingkat penerimaan panelis terhadap produk-produk tersebut adalah 3,68 yang berada pada taraf agak suka sampai suka.

Sedangkan untuk nilai tertinggi terhadap kekentalan yang disukai panelis adalah 4,35 (suka sampai sangat suka) pada madu sawo yang dievaporasi pada suhu $60^{\circ} \mathrm{C}$ selama 10 jam. Kekentalan madu berhubungan dengan kadar air, dimana kadar air produk ini adalah $19,86 \%$ (Putri et al. 2018) dan sudah memenuhi syarat mutu madu menurut SNI 01-3545-2004, yaitu maksimum air $22 \%$ (b/b), serta berhubungan juga dengan total padatan tak larut air sebesar $1,17 \%$, dimana padatan tidak larut air yang tinggi akan menaikkan viskositas larutan.

\section{Uji Pembeda Madu}

Uji pembeda dilakukan secara fisik terhadap madu buah sawo terbaik, yaitu madu hasil evaporasi pada suhu $60^{\circ} \mathrm{C}$ selama 10 jam (Putri et al. 2018) dibandingkan dengan madu asli (merk edar Madu Sumbawa) dan sampel madu 
buah kurma yang beredar di pasar (Sari Kurma Jadied Propolis) serta dibandingkan juga dengan hasil madu sawo yang dikentalkan dengan cara pemasakan di atas kompor. Hasil uji pembeda madu dapat dilihat pada Tabel 5.

Tabel 5. Rata-rata uji pembeda madu sawo terhadap madu asli dan madu buah kurma

\begin{tabular}{rcc}
\hline Perbandingan & Terhadap $\mathbf{Y}$ & Terhadap $\mathbf{Z}$ \\
\hline $\mathrm{X}$ & 2 & 1 \\
\hline Keteranga $: \mathrm{X}$ & $=$ madu buah sawo hasil evaporasi pada suhu & $60^{\circ} \mathrm{C}$ selama 10 jam \\
$\mathrm{Y}$ & $=$ madu asli \\
$\mathrm{Z}$ & $=$ madu kurma \\
1 & $=$ suka daripada, 2 = tidak suka daripada
\end{tabular}

Dari Tabel 5. dapat dilihat bahwa penilaian panelis terhadap madu sawo hasil evaporasi (X) dibandingkan dengan madu buah kurma yang beredar (Z), bahwa rata-rata panelis lebih menyukai produk $X$ daripada $Z$. Hal ini karena warnanya yang lebih cerah dan kekentalannya lebih menyerupai madu asli. Madu kurma berwarna sangat gelap dan sangat pekat. Selain itu, madu sawo juga memiliki rasa agak lebih manis daripada madu kurma dan memiliki aroma buah sawo yang khas.

Madu sawo (X) tidak lebih disukai dibandingkan madu asli (Y), karena madu sawo berwarna lebih keruh, memiliki aroma gula yang agak menyengat dibandingkan madu, serta memiliki penampilan yang kurang menarik dibandingkan madu asli. Rasa madu asli lebih disukai karena merupakan madu alami yang berasal dari pencernaan lebah dan belum mengalami proses pengolahan yang menyebabkan terjadinya perubahan warna atau rasa pada madu.

\section{KESIMPULAN}

1. Kenaikan suhu dan waktu evaporasi dapat meningkatkan persentase total padatan tak larut air pada madu sawo.

2. Madu sawo yang dievaporasi pada suhu $60^{\circ} \mathrm{C}$ selama $10 \mathrm{jam}\left(\mathrm{A}_{3} \mathrm{~B}_{2}\right)$ memiliki rata-rata nilai warna 3,75 (agak suka sampai suka), rata-rata nilai aroma 3,05 agak suka sampai suka), dan rata-rata nilai kekentalan 4,35 (suka sampai sangat suka).

\section{DAFTAR PUSTAKA}

Astawan, M. 2010. Budidaya Tanaman Sawo. Jakarta: Penebar Swadaya (BSN) Badan Standar Nasional. 2004. SNI Madu (SNI 01-3545-2004) 
(BSN) Badan Standar Nasional. 1992. SNI Gula (SNI 01-2891-1992)

Balerdi CF, Crane JH, Maguire I. 2008. Sapodilla growing in the florida home landscape. University of Florida IFAS Extension. Hal: 1-10

(BPS) Badan Pusat Statistik Kabupaten Tanah datar. 2016. Kecamatan batipuh selatan dalam angka 2016 (batipuh selatan sub district in figures). Katalog BPS: 1102001-1305021. Hal:35

(BPS) Badan Pusat Statistik Kabupaten Tanah datar. 2016. Ringkasan eksekutif pertanian kabupaten tanah datar 2016 (executive summary of agriculture in tanah datar regency). Katalog BPS: 5101006.1305. hal:16

Jangam SV, Joshi VS, Mujumdar AS, Thorat BN. 2008. Studies on dehydration of sapota (Achras zapota). Drying Technology: An International Journal, 26:3, 369-377. Doi: 10.1080/07373930801898190

Kusmiyati ED, Trisnowati S, Ambarwati E. 2014. Kajian budidaya dan produktivitas sawo (Manilkara zapota (L.) van Royen) di Dusun Pasutan, Bogoran dan Pepe, Desa Trirenggo, Kabupaten Bantul, Yogyakarta. Vegetalika 3(1): 66-78

Putri NE, Aisman, Novelina. 2018. Madu buah sebagai alternatif pemanjangan umur simpan saat musim panen raya buah sawo (Achras zapota L.). Prosiding Seminar Nasional Hasil Penelitian Pertanian VII-Fakultas Pertanian UGM. ISSN: 2442-7314

Winarno FG. 2004. Kimia Pangan dan Gizi. Jakarta: PT. Gramedia Pustaka Utama 